\title{
Pemodelan Indeks Keparahan Kemiskinan di Indonesia Menggunakan Analisis Regresi Robust
}

\author{
Melva Hilda Stephanie Situmorang ${ }^{1}$ dan Yuliana Susanti ${ }^{2}$ \\ ${ }^{1,2}$ Program Studi Statistika, Fakultas MIPA, Universitas Sebelas Maret \\ ${ }^{1}$ stephaniemelva@student.uns.ac.id, ${ }^{2}$ yulianasusanti@staff.uns.ac.id
}

\begin{abstract}
Poverty is one indicator to see the success of development in a country. The Poverty Severity Index can be used as one measure of the magnitude of poverty in an area. In the Poverty Severity Index data in Indonesia, in 2018 there were some outliers, so to analyze it used robust regression. The purpose of this study is to determine the significant factors on the Poverty Severity Index in Indonesia using robust regression with the $M$-estimation method. The results showed that the Poverty Severity Index model in Indonesia using robust regression was influenced by Gini Ratio, Percentage of Poor Population, and Pure Participation Rate with $R$-square = $94,8 \%$.
\end{abstract}

Keywords: Poverty Severity Index, robust regression.

\section{Pendahuluan}

Kemiskinan merupakan salah satu indikator untuk melihat keberhasilan pembangunan di suatu negara [1,2]. Jika tingkat kemiskinan rendah, maka program pembangunan telah berhasil dan dapat meningkatkan kesejahteraan hidup. Menurut Yacoub [3], kemiskinan merupakan persoalan yang mendasar karena kemiskinan menyangkut pemenuhan kebutuhan paling mendasar dalam kehidupan dan merupakan masalah yang bersifat global. Berdasarkan data dari Badan Pusat Statistik (BPS), jumlah penduduk miskin perkotaan dan perdesaan di Indonesia cenderung terus menurun sejak tahun 2006 dan pada tahun 2017 mengalami penurunan yang cukup besar. Hal ini tentu saja merupakan suatu pertanda yang baik karena artinya perekonomian Indonesia mengalami peningkatan.

Indeks Keparahan Kemiskinan (Proverty Severity Index-P2) memberikan gambaran mengenai penyebaran pengeluaran antara penduduk miskin. Semakin tinggi nilai indeks, maka semakin tinggi juga ketimpangan pengeluaran di antara penduduk miskin. Indeks Keparahan Kemiskinan digunakan untuk mengetahui keberagaman jumlah pengeluaran penduduk miskin di suatu daerah [4].

Penelitian mengenai kemiskinan sebelumnya telah dilakukan oleh. Ferezagia [5] mengenai analisis klaster tingkat kemiskinan di Indonesia menggunakan analisis cluster non hierarki dan hierarki. Data yang digunakan merupakan data cross section tahun 2017. 
Dari penelitian yang dilakukan Ferezagia didapatkan 3 kelompok dengan indeks kemiskinan tertinggi ada pada kelompok 3.

Penelitian mengenai kemiskinan juga dilakukan oleh Jonaidi [6] karena menurutnya, pendidikan merupakan salah satu indikator yang menggambarkan Sumber Daya Manusia (SDM). Jika tingkat pendidikan seseorang rendah, produktivitasnya juga akan cenderung rendah. Kondisi ini tentu saja berpotensi untuk meningkatkan kemiskinan. Taraf kesehatan dan gizi yang rendah menyebabkan rendahnya daya tahan fisik dan daya pikir sehingga menghambat kemampuan seseorang tersebut dalam bekerja.

Berdasarkan latar belakang itulah, dilakukan penelitian untuk melihat variabel lain yang juga mempengaruhi faktor kemiskinan selain taraf kesehatan dan gizi seseorang. Pemodelan Indeks Keparahan Kemiskinan di Indonesia pada tahun 2018 menggunakan regresi robust dengan estimasi- $M$ karena data Indeks Keparahan Kemiskinan terkontaminasi pencilan. Penelitian ini dilakukan untuk mengetahui variabel yang berpengaruh terhadap Indeks Keparahan Kemiskinan diantara Gini Ratio, Persentase Penduduk Miskin, dan Angka Partisipasi Murni .

\section{Landasan Teori}

2.1. Regresi Linier Ganda. Analisis regresi linier ganda adalah analisis yang mengkaji hubungan antara satu variabel dependent dengan beberapa variabel independen [7]. Model regresi ganda dalam bentuk matriks adalah

$\boldsymbol{Y}=\boldsymbol{X} \boldsymbol{\beta}+\boldsymbol{e}$.

dengan

$$
\boldsymbol{Y}=\left[\begin{array}{c}
Y_{1} \\
Y_{2} \\
\vdots \\
Y_{n}
\end{array}\right], \quad \boldsymbol{X}=\left[\begin{array}{ccccc}
1 & X_{11} & X_{21} & \cdots & X_{k 1} \\
1 & X_{12} & X_{22} & \cdots & X_{k 2} \\
\vdots & \vdots & \vdots & & \vdots \\
1 & X_{1 n} & X_{2 n} & \cdots & X_{k n}
\end{array}\right], \quad \boldsymbol{\beta}=\left[\begin{array}{c}
\beta_{0} \\
\beta_{1} \\
\vdots \\
\beta_{k}
\end{array}\right], \quad \boldsymbol{e}=\left[\begin{array}{c}
e_{1} \\
e_{2} \\
\vdots \\
e_{n}
\end{array}\right]
$$

dengan $\boldsymbol{Y}$ menyatakan vektor variabel dependen berukuran $n \times 1, \boldsymbol{X}$ menyatakan matriks variabel independen berukuran $n \times m$, dengan $m=k+1$, $\boldsymbol{\beta}$ menyatakan vektor parameter model berukuran $m \times 1$ dan e menyatakan vektor residu berukuran $n \times 1$ [8].

Estimator untuk persamaan (1) dengan menggunakan metode Ordinary Least Square (OLS) diperoleh

$$
\boldsymbol{X}^{\prime} \boldsymbol{X} \widehat{\boldsymbol{\beta}}=\boldsymbol{X}^{\prime} \boldsymbol{Y}
$$


dengan $\boldsymbol{X}^{\prime}$ matriks berukuran $m \times n$.

Untuk menyelesaikan persamaan (2), kedua ruas dikalikan dengan invers dari $\left(\boldsymbol{X}^{\prime} \boldsymbol{X}\right)$.

Oleh karena itu, diperoleh estimator kuadrat terkecil dari $\widehat{\boldsymbol{\beta}}$ berbentuk

$$
\begin{aligned}
& \left(\boldsymbol{X}^{\prime} \boldsymbol{X}\right)^{-1} \boldsymbol{X}^{\prime} \boldsymbol{X} \widehat{\boldsymbol{\beta}}=\left(\boldsymbol{X}^{\prime} \boldsymbol{X}\right)^{-1} \boldsymbol{X}^{\prime} \boldsymbol{Y} \\
& \widehat{\boldsymbol{\beta}}=\left(\boldsymbol{X}^{\prime} \boldsymbol{X}\right)^{-1} \boldsymbol{X}^{\prime} \boldsymbol{Y}
\end{aligned}
$$

2.2. Pencilan (Outlier). Pencilan merupakan nilai ekstrem dari suatu pengamatan. Menurut Kurniawati [9], metode yang dapat digunakan untuk mengidentifikasi adanya pencilan yang berpengaruh pada koefisien regresi salah satunya adalah metode Difference Fitted value of FITS (DFFITS) atau Standardized DFFITS. Nilai DFFITS dapat dihitung menggunakan rumus sebagai berikut:

$$
(\text { DFFITS })_{i}=\frac{Y_{i}-\hat{Y}_{-i}}{\sqrt{S_{-i}^{2} h_{i i}}} \text { atau }(\text { DFFITS })_{i}=\frac{e_{i}}{\sqrt{S_{-i}^{2} h_{i i}}}
$$

dimana $Y_{i}$ merupakan nilai ekstrem $Y$ pada pengamatan ke $-i$, sedangkan $\hat{Y}_{-i}$ merupakan nilai taksiran $Y$ tanpa pengamatan $\mathrm{ke}-i, S_{-i}^{2}$ merupakan jumlah kuadrat residu tanpa pengamatan $\mathrm{ke}-i, t_{i}$ menyatakan studentized deleted residual untuk kasus ke- $i$, dan $h_{i i}$ menyatakan nilai leverage (pengaruh) untuk kasus ke- $i$

Menurut Kurniawati [9], rumus lain DFFITS adalah

$$
(\text { DFFITS })_{i}=t_{i}\left(\frac{h_{i i}}{1-h_{i i}}\right)^{2}
$$

dengan

$$
t_{i}=e_{i} \sqrt{\frac{n-p-1}{J K G\left(1-h_{i i}\right)-e_{i}^{2}}}
$$

dimana $e_{i}$ adalah residu ke $-i$ dan JKG adalah Jumlah Kuadrat Galat (residu), yang memiliki rumus sebagai berikut:

$$
J K G=\sum_{i=1}^{n} \varepsilon_{i}^{2}
$$


Suatu data yang mempunyai nilai absolute (mutlak) DEFFITS $\geq 2 \sqrt{k / n}$ maka diidentifikasikan sebagai pencilan, dengan $k$ banyaknya variabel bebas yang digunakan dan $n$ banyaknya observasi [9].

\subsection{Uji Asumsi Klasik dalam Regresi Linier Berganda}

a.) Uji Normalitas Residu. Uji normalitas data dilakukan dengan uji KolmogorovSmirnov

Uji Hipotesis

i. $H_{0}$ : residu berdistribusi normal

$H_{1}$ : residu tidak berdistribusi normal

ii. Taraf signifikansi $\alpha$

iii. Menghitung statistik uji

$$
D_{\text {hitung }}=\operatorname{Max}\left|F_{n}(x)-F^{*}(x)\right|
$$

dengan $F_{n}(x)$ adalah fungsi distribusi kumulatif empiris, dan $F^{*}(x)$ adalah fungsi distribusi kumulatif normal

iv. Menentukan daerah kritis

$H_{0}$ ditolak jika $D_{\text {hitung }}>D_{(1-\alpha, n)}$ dengan $D_{(1-\alpha, n)}$ didapat dari tabel Kolmogorov-Smirnov.

v. Menentukan kesimpulan

b). Uji Homogenitas Variansi Residu. Uji homogenitas variansi residu dilakukan dengan uji Breusch Pagan

Uji Hipotesis

i. $\quad H_{0}$ : model regresi bersifat homoskedastisitas

$H_{1}$ : model regresi tidak bersifat homoskedastisitas

ii. Taraf signifikansi $\alpha$

iii. Keputusan uji: menolak $H_{0}$ apabila $p_{\text {value }}<\alpha$

c). Uji Autokorelasi Residu. Uji autokorelasi dapat digunakan uji Durbin-Watson, dengan uji hipotesis

i. $\quad H_{0}: \rho=0$, artinya tidak terdapat autokorelasi $H_{1}: \rho \neq 0$, artinya terdapat autokorelasi

ii. Taraf signifikansi $\alpha$ 
iii. Keputusan Uji

Jika dapat ditunjukkan $d_{u}<d<4-d_{u}$, dimana

$d=d$-hitung Durbin-Watson

$d_{u}=$ nilai kritis untuk batas atas dari tabel Durbin-Watson

maka dapat disimpulkan bahwa dalam model tidak terjadi autokorelasi

d). Uji Multikolinieritas. Uji Multikolinieritas dilakukan dengan cara menentukan nilai Variance Inflation Factor (VIF), jika VIF $<10$ maka asumsi non multikolinearitas dipenuhi.

2.4. Estimasi- $\boldsymbol{M}$. Beberapa peneliti mengembangkan metode untuk mengatasi dampak pencilan apabila metode Ordinary Least Square (OLS) digunakan. Metode ini disebut estimasi-M [11]. Menurut Li, et al. [11] dan Susanti [12], penggunaan metode kuadrat terkecil tidak akan sesuai dalam menyelesaikan masalah yang mengandung pengamatan outlier atau ekstrem, karena asumsi normalitas tidak dapat dipenuhi. Estimasi- $M$ mengantisipasi hal ini dengan mendefinisikan fungsi $\varepsilon, \rho(\varepsilon)$ yang disebut fungsi Huber. Masing-masing $b_{0}, b_{1}, \ldots, b_{p}$ dalam estimasi- $M$ adalah penaksir $\beta_{0}, \beta_{1}, \ldots, \beta_{p}$ dipilih sedemikian rupa sehingga $\sum \rho(\varepsilon)$ minimum dan fungsi Huber didefinisikan sebagai

$$
\rho(\varepsilon)=\left\{\begin{array}{cc}
\varepsilon^{2} & \text { jika }-k<\varepsilon<k \\
2 k|\varepsilon|-k^{2} & \text { jika } \varepsilon<-k \text { atau } \varepsilon>k
\end{array}\right.
$$

di mana $k=1,5 \hat{\sigma}$. Untuk memperkirakan $\sigma$ digunakan $\hat{\sigma}=1,483$ MAD dimana Median of Absolute Deviation (MAD) adalah median dari absolut yang tersisa. Untuk mendapatkan nilai estimasi- $M$, diperlukan algoritma penghitungan. Algoritma estimasi- $M$ berikut diberikan oleh Birkes dan Dodge [13].

1. Menentukan prediksi model menggunakan metode kuadrat terkecil $\hat{y}=b_{0}^{0}+$ $b_{1}^{0} x_{i 1}+\ldots+b_{p}^{0} x_{i p}$, dan menghitung $e_{i}^{0}=y_{i}-\hat{y}_{i}^{0}$ dan kemudian menghitung $\hat{\sigma}=1,483$ MAD.

2. Memotong $e_{i}^{0}$ di mana $e_{i}^{*}=1,5 \hat{\sigma}$ jika $e_{i}^{0}>1,5 \hat{\sigma}$ dan $e_{i}^{*}=-1,5 \hat{\sigma}$ jika $e_{i}^{0}<$ $-1,5 \hat{\sigma}$.

3. Menghitung $y_{i}^{*}=e_{i}^{*}+\hat{y}_{i}^{0}$ dan kemudian menemukan nilai $b^{0}$ dengan menggunakan metode kuadrat terkecil. Proses iterasi berlanjut sampai nilai yang diperoleh $b^{0}$ sama dengan iterasi sebelumnya. Nilai $b^{0}$ diperoleh dari regresi dengan estimasi- $M$. 


\subsection{Uji Signifikansi Model}

Hipotesis:

$H_{0}: \beta_{j}=0 \forall_{j}, j=q+1, q+2, \ldots, p$

$H_{1}: \exists_{j} \in \beta_{j} \neq 0 \forall_{j}, j=q+1, q+2, \ldots, p$

dengan $q$ merupakan jumlah variabel independen $\beta_{i}$ yang dimasukkan dalam model, $p$ merupakan jumlah variabel independen yang digunakan. Oleh karena itu model menjadi $Y_{i}=\beta_{0}+\beta_{1} X_{i 1}+\cdots+\beta_{q} X_{i q}+\varepsilon_{i}$

Statistik uji:

$F_{m}=\frac{S T R_{\text {reduce }}-S T R_{\text {full }}}{(p-q) \hat{\lambda}}$

$\hat{\lambda}=\frac{\left(\frac{n}{m}\right) \sum\left(e_{i} *\right)^{2}}{n-p-1}$

Dengan Sum of Transformed Residuals (STR) merupakan jumlah yang tersisa ditransformasikan, dimana $S T R_{\text {reduce }}$ dan $S T R_{\text {full }}$ diperoleh dari model full dan model reduced. Algoritma $S T R_{\text {full }}$ :

1. Menghitung $e_{i}$, dan $\hat{\sigma}=1.483 M A D$

2. Memotong nilai $e_{i}$ untuk mendapatkan nilai $e_{i}$ dari $\rho(\varepsilon)$

dengan

$$
\rho(\varepsilon)=\left\{\begin{array}{cc}
\varepsilon^{2} & \text { jika }-k<\varepsilon<k \\
2 k|\varepsilon|-k^{2} & \text { jika } \varepsilon<-k \text { atau } \varepsilon>k
\end{array}\right.
$$

menghitung $S T R_{\text {reduce }}$ dengan cara sama dengan menghitung $S T R_{\text {full }} l, m$ merupakan jumlah $e_{i}$ yang tidak dipotong. $H_{0}$ ditolak jika $F_{m}>F$ tabel dengan derajat bebas $(p-q) ;(n-p-1)$

\section{Hasil dan Pembahasan}

Variabel-variabel yang digunakan dalam penelitian ini adalah Indeks Keparahan Kemiskinan $(Y)$, Gini Ratio $\left(X_{1}\right)$, Persentase Penduduk Miskin $\left(X_{2}\right)$, dan Angka Partisipasi Murni $\left(X_{3}\right)$ di Indonesia pada tahun 2018, diperoleh dari Badan Pusat Statistika 2019 [4]. Berdasarkan data tersebut dan menggunakan metode OLS didapatkan persamaan regresi: 
$\hat{y}=0,73+0,65 X_{1}+0,07151 X_{2}-0,0125 X_{3}$

Selanjutnya dilakukan uji asumsi klasik. Berdasarkan Gambar 1, diketahui $p_{\text {value }}=$ $0,025<\alpha=0,05$ maka asumsi normalitas tidak dipenuhi..

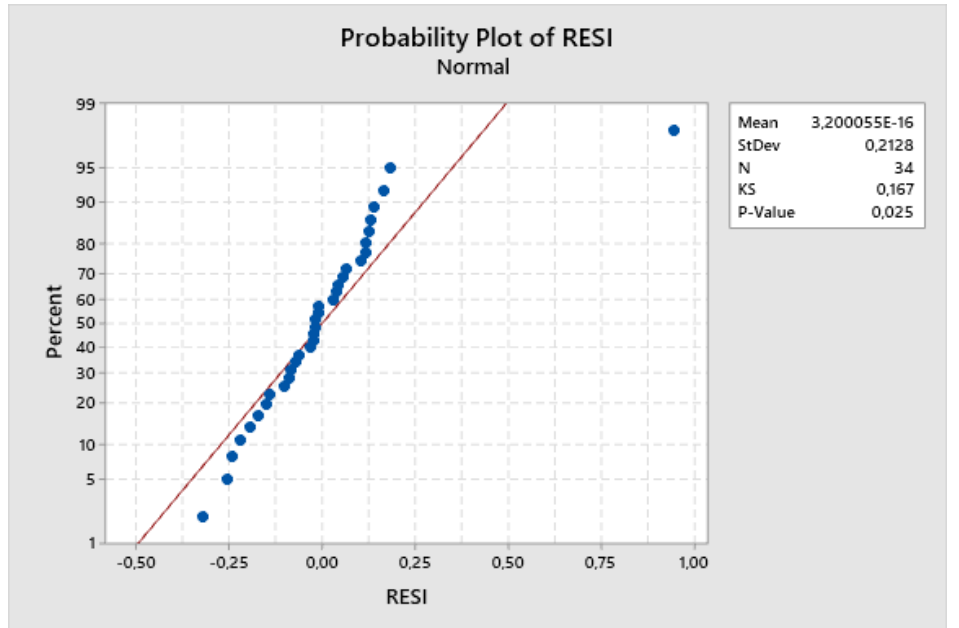

Gambar 1. Plot Normal

Selanjutnya dari uji multikolinearitas didapatkan nilai VIF untuk variabel $X_{1}, X_{2}$, dan $X_{3}$ di antara nilai 1-10 yaitu sebesar 1,102; 1,572; dan 1,474 sehingga tidak terjadi multikolinieritas. Kemudian uji autokorelasi didapatkan nilai Durbin-Watson sebesar 1,826 dan nilai $d_{u}$ dan $d_{l}$ pada tabel Durbin-Watson $(3,34)$ sebesar 1,2707 dan 1,6519, maka nilai autokorelasi di antara 1,6519 $<1,826<2,3481$ sehingga tidak terjadi autokorelasi. Selanjutnya dengan uji Breusch Pagan menggunakan SPSS didapatkan nilai $p_{\text {value }}=0,078$. Karena $p_{\text {value }}=0,078>\alpha=0,05$ maka dikatakan bahwa variabel tidak ada gejala heteroskedastisitas.

Oleh karena ada uji asumsi klasik yang dilanggar yaitu uji asumsi normalitas. Terdapat dua pengamatan pencilan yaitu data ke-33 dan data ke-34, dimana nilai DEFIT data ke-33 dan data ke-34 adalah 4,171285 dan 4,551518 yang > nilai $2 \sqrt{\frac{p}{n}}$ sebesar 0,685994. Oleh karena itu dilakukan regresi robust.

Berdasarkan algoritma estimasi- $M$, selanjutnya menghitung nilai $\hat{y}_{i}^{0}, e_{i}^{0}=y_{i}-$ $\hat{y}_{i}^{0}$ dan median deviasi absolut $\left|e_{i}^{0}\right|=0,102288$, kemudian menghitung nilai $1,5 \hat{\sigma}=$ 0,227540. Jika nilai $\left|e_{i}^{0}\right|<k$, maka $e_{i}^{*}=e_{i}^{0}$. Sementara itu, empat nilai $\left|e_{i}^{0}\right|>k$, maka residu ini diubah menjadi 0,227540 dan menghitung nilai $y_{i}^{*}=e_{i}^{*}+\hat{y}_{i}^{0}$. Nilai $y_{i}^{*}$ digunakan untuk menghitung $b^{0}$ pada iterasi berikutnya. Iterasi berhenti ketika nilai $b^{0}$ sama dengan $b^{0}$ pada iterasi sebelumnya. Hasil dalam setiap iterasi disajikan pada Tabel 


1. Proses berhenti pada iterasi ke-16 dengan nilai
$b^{0}=(1,365 ; 0,457 ; 0,05772 ;-0,01712)$. Jadi model regresi linier robust dengan estimasi- $M$ adalah

$\hat{y}=1,365+0,457 x_{1}+0,05772 x_{2}-0,01712 x_{3}$

dengan $R$-square $(a d j)=94,80 \%$ dan $s=0,0881602$, yang berarti variabel independen yang digunakan dalam model (Gini Ratio $\left(X_{1}\right)$, Persentase Penduduk Miskin $\left(X_{2}\right)$, dan Angka Partisipasi Murni $\left(X_{3}\right)$ ) mampu menjelaskan sebesar 94,80\% variasi variabel dependen (Indeks Keparahan Kemiskinan ( $Y$ )), sedangkan sisanya sebesar 5,2\% dipengaruhi atau dijelaskan oleh variabel lain yang tidak dimasukkan dalam model tersebut. Model regresi (13) menunjukkan bahwa peningkatan satu satuan Gini Ratio $\left(X_{1}\right)$ dan Persentase Penduduk Miskin $\left(X_{2}\right)$ akan meningkatkan Indeks Keparahan Kemiskinan (Y) masing-masing sebesar 0,457 dan 0,05772. Peningkatan satu satuan Angka Partisipasi Murni $\left(X_{3}\right)$ akan menurunkan Indeks Keparahan Kemiskinan $(Y)$ sebesar 0,01712 .

Tabel 1. Nilai $b^{0}$, MAD, Residual $C u t$, dan $y_{i}^{*}$ untuk masing-masing iterasi

\begin{tabular}{llll}
\hline No & \multicolumn{1}{c}{$b^{0}$} & \multicolumn{1}{c}{ MAD } & \multicolumn{1}{c}{ Residual Cut } \\
\hline 1 & $(0,731514 ; 0,647312 ; 0,071512 ;-$ & 0,102288 & $7,14,18,33$ \\
& $0,012504)$ & & \\
2 & $(1,09979 ; 0,41034 ; 0,06350 ;-0,01474)$ & 0,0685405 & $7,13,14,18,19,30,32,33$ \\
3 & $(1,24536 ; 0,45255 ; 0,05989 ;-0,01606)$ & 0,0624386 & $13,14,19,30,32,33$ \\
4 & $(1,31853 ; 0,46111 ; 0,05847 ;-0,01672)$ & 0,0624239 & 19,33 \\
5 & $(1,34375 ; 0,46057 ; 0,05802 ;-0,01694)$ & 0,0621141 & $19,24,33$ \\
6 & $(1,35459 ; 0,45939 ; 0,05785 ;-0,01703)$ & 0,0619625 & $19,24,33$ \\
7 & $(1,36026 ; 0,45806 ; 0,05778 ;-0,01708)$ & 0,0618694 & $19,24,33$ \\
8 & $(1,36303 ; 0,45730 ; 0,05775 ;-0,01710)$ & 0,0618216 & $19,24,33$ \\
9 & $(1,36435 ; 0,45692 ; 0,05773 ;-0,01711)$ & 0,0617984 & $19,24,33$ \\
10 & $(1,36498 ; 0,45673 ; 0,05773 ;-0,01712)$ & 0,0617874 & $19,24,33$ \\
11 & $(1,36527 ; 0,45664 ; 0,05772 ;-0,01712)$ & 0,0617822 & $19,24,33$ \\
12 & $(1,36541 ; 0,45660 ; 0,05772 ;-0,01712)$ & 0,0617798 & $19,24,33$ \\
13 & $(1,36547 ; 0,45658 ; 0,05772 ;-0,01712)$ & 0,0617786 & $19,24,33$ \\
14 & $(1,36550 ; 0,45657 ; 0,05772 ;-0,01712)$ & 0,0617781 & $19,24,33$ \\
15 & $(1,36552 ; 0,45657 ; 0,05772 ;-0,01712)$ & 0,0617778 & $19,24,33$ \\
16 & $(1,36552 ; 0,45657 ; 0,05772 ;-0,01712)$ & 0,0617778 & $19,24,33$ \\
\hline
\end{tabular}


Dari model regresi linier (3), pengujian hipotesis dilakukan untuk menentukan apakah Gini Ratio $\left(X_{1}\right)$, Persentase Penduduk Miskin $\left(X_{2}\right)$, dan Angka Partisipasi Murni $\left(X_{3}\right)$ memiliki pengaruh terhadap Indeks Keparahan Kemiskinan $(Y)$ di Indonesia pada tahun 2018. Ada tujuh kemungkinan reduced models pada model regresi linier dengan tiga variabel independen yaitu

$Y_{i}=\beta_{0}+\varepsilon_{i}$

$Y_{i}=\beta_{0}+\beta_{1} X_{i 1}+\varepsilon_{i}$

$Y_{i}=\beta_{0}+\beta_{2} X_{i 2}+\varepsilon_{i}$

$Y_{i}=\beta_{0}+\beta_{3} X_{i 3}+\varepsilon_{i}$

$Y_{i}=\beta_{0}+\beta_{1} X_{i 1}+\beta_{2} X_{i 2}+\varepsilon_{i}$

$Y_{i}=+\beta_{1} X_{i 1}+\beta_{3} X_{i 3}+\varepsilon_{i}$

$Y_{i}=\beta_{0}+\beta_{2} X_{i 2}+\beta_{3} X_{i 3}+\varepsilon_{i}$

Nilai $S T R_{\text {full }}$ dihitung dari model regresi (3) sebelum menguji hipotesis untuk setiap reduced models. Berdasarkan algoritma perhitungan $S T R_{\text {full }}$, langkah pertama adalah menghitung nilai kesalahan $e_{i}$ dari model regresi (3). Nilai MAD didapatkan sebesar 0,0617778 dengan $k=0,137425$ lalu menghitung $\rho\left(\varepsilon_{i}\right)$. Nilai $S T R_{\text {full }}$ adalah jumlah nilai $\rho\left(\varepsilon_{i}\right)$ yaitu sebesar 0,233197 . Kemudian didapatkan nilai

$$
\hat{\lambda}=\frac{(n / m) \sum\left(e^{*}\right)^{2}}{n-p-1}=0,0085244
$$

Selanjutnya menghitung $S T R_{\text {reduced }}$ dari model tereduksi (4) - (10). Langkahlangkah menghitung $S T R_{\text {reduced }}$ sama dengan menghitung $S T R_{\text {full }}$, hanya saja nilai $k$ tetap (k=0,137435). $S T R_{\text {reduced }}$ dari model (4) - (10) ditunjukkan dalam Tabel 2.

Tabel 2. STR $R_{\text {reduced }}$

\begin{tabular}{ll}
\hline Model & STR $_{\text {reduced }}$ \\
\hline$(4)$ & 0,292533 \\
$(5)$ & 0,265187 \\
$(6)$ & 0,236986 \\
$(7)$ & 0,351284 \\
$(8)$ & 0,226458 \\
$(9)$ & 0,323030 \\
$(10)$ & 0,199080 \\
\hline
\end{tabular}


a. Model (4)

$H_{0}: \beta_{i}=0 \forall_{i}, i=1,2,3$ (Gini Ratio, Persentase Penduduk Miskin, dan Angka Partisipasi Murni tidak berpengaruh signifikan terhadap Indeks Keparahan Kemiskinan)

$H_{1}: \exists_{i} \beta_{i} \neq 0, i=1,2,3$ (Paling tidak salah satu dari Gini Ratio, Persentase Penduduk Miskin, atau Angka Partisipasi Murni berpengaruh signifikan terhadap Indeks Keparahan Kemiskinan)

Dengan statistik uji: $F_{m}=\frac{\text { STR }_{\text {reduced }}-S T R_{\text {full }}}{(p-q) \hat{\lambda}}=\frac{0,292533-0,233167}{(3-0) 0,0085244}=2,32144$ $p=3, q=0,(n-p-1)=(34-3-1)=30, F_{(0,1 ; 3-0,34-3-1)}=F_{(0,1 ; 3,30)}=2,28$

Karena $F_{\text {hitung }}=2,32144,<F_{(0,1 ; 3,30)}=2,28$ maka $H_{0}$ ditolak yang berarti paling tidak salah satu dari Gini Ratio, Persentase Penduduk Miskin, atau Angka Partisipasi Murni berpengaruh signifikan terhadap Indeks Keparahan Kemiskinan.

b. Model (5)

$H_{0}: \beta_{i}=0 \forall_{i}, i=2,3$ (Persentase Penduduk Miskin, atau Angka Partisipasi Murni tidak berpengaruh signifikan terhadap Indeks Keparahan Kemiskinan)

$H_{1}: \exists_{i} \beta_{i} \neq 0, i=2,3$ (Paling tidak salah satu dari Persentase Penduduk Miskin, atau Angka Partisipasi Murni berpengaruh signifikan terhadap Indeks Keparahan Kemiskinan)

Dengan statistik uji: $F_{m}=\frac{S T R_{\text {reduced }}-S T R_{\text {full }}}{(p-q) \hat{\lambda}}=\frac{0,265187-0,233167}{(3-1) 0,0085244}=1,87817$ $p=3, q=1,(n-p-1)=(34-3-1)=30, F_{(0,1 ; 3-1,34-3-1)}=F_{(0,1 ; 2,30)}=2,49$

Karena $F_{\text {hitung }}=1,87817<F_{(0,1 ; 2,30)}=2,49$ maka $H_{0}$ gagal ditolak yang berarti Persentase Penduduk Miskin dan Angka Partisipasi Murni tidak berpengaruh signifikan terhadap Indeks Keparahan Kemiskinan.

c. Model (6)

$H_{0}: \beta_{i}=0 \forall_{i}, i=1,3$ (Gini Ratio, atau Angka Partisipasi Murni tidak berpengaruh signifikan terhadap Indeks Keparahan Kemiskinan)

$H_{1}: \exists_{i} \beta_{i} \neq 0, i=1,3 \quad$ (Paling tidak salah satu dari Gini Ratio, atau Angka Partisipasi Murni berpengaruh signifikan terhadap Indeks Keparahan Kemiskinan)

Dengan statistik uji: $F_{m}=\frac{S T R_{\text {reduced }}-S T R_{\text {full }}}{(p-q) \hat{\lambda}}=\frac{0,236986-0,233167}{(3-1) 0,0085244}=0,224002$ $p=3, q=1,(n-p-1)=(34-3-1)=30, F_{(0,1 ; 3-1,34-3-1)}=F_{(0,1 ; 2,30)}=2,49$ 
Karena $F_{\text {hitung }}=0,224002<F_{(0,1 ; 2,30)}=2,49$ maka $H_{0}$ gagal ditolak yang berarti Gini Ratio dan Angka Partisipasi Murni tidak berpengaruh signifikan terhadap Indeks Keparahan Kemiskinan.

d. Model (7)

$H_{0}: \beta_{i}=0 \forall_{i}, i=1,2 \quad($ Gini Ratio atau Persentase Penduduk Miskin tidak berpengaruh signifikan terhadap Indeks Keparahan Kemiskinan)

$H_{1}: \exists_{i} \beta_{i} \neq 0, i=1,2$ (Paling tidak salah satu dari Gini Ratio atau Persentase Penduduk Miskin berpengaruh signifikan terhadap Indeks Keparahan Kemiskinan)

Dengan statistik uji: $F_{m}=\frac{S T R_{\text {reduced }}-S T R_{\text {full }}}{(p-q) \hat{\lambda}}=\frac{0,351284-0,233167}{(3-1) 0,0085244}=6,92824$

$p=3, q=1,(n-p-1)=(34-3-1)=30, F_{(0,1 ; 3-1,34-3-1)}=F_{(0,1 ; 2,30)}=2,49$

Karena $F_{\text {hitung }}=6,92824>F_{(0,1 ; 2,30)}=2,49$ maka $H_{0}$ ditolak yang berarti paling tidak salah satu dari Gini Ratio atau Persentase Penduduk Miskin berpengaruh signifikan terhadap Indeks Keparahan Kemiskinan.

e. Model (8)

$H_{0}: \beta_{3}=0$ (Angka Partisipasi Murni tidak berpengaruh signifikan terhadap Indeks Keparahan Kemiskinan)

$H_{1}: \beta_{3} \neq 0$ (Angka Partisipasi Murni berpengaruh signifikan terhadap Indeks Keparahan Kemiskinan)

Dengan statistik uji: $F_{m}=\frac{S T R_{\text {reduced }}-S T R_{\text {full }}}{(p-q) \hat{\lambda}}=\frac{0,226458-0,233167}{(3-2) 0,0085244}=-0,786945$

$p=3, q=2,(n-p-1)=(34-3-1)=30, F_{(0,1 ; 3-2,34-3-1)}=F_{(0,1 ; 1,30)}=2,88$

Karena $F_{\text {hitung }}=-0,786945<F_{(0,1 ; 1,30)}=2,88$ maka gagal menolak $H_{0}$ yang berarti Angka Partisipasi Murni tidak berpengaruh signifikan terhadap Indeks Keparahan Kemiskinan.

f. Model (9)

$H_{0}: \beta_{2}=0$ (Persentase Penduduk Miskin tidak berpengaruh signifikan terhadap Indeks Keparahan Kemiskinan)

$H_{1}: \beta_{2} \neq 0$ (Persentase Penduduk Miskin berpengaruh signifikan terhadap Indeks Keparahan Kemiskinan)

Dengan statistik uji: $F_{m}=\frac{S T R_{\text {reduced }}-S T R_{\text {full }}}{(p-q) \hat{\lambda}}=\frac{0,323030-0,233167}{(3-2) 0,0085244}=10,5419$

$p=3, q=2,(n-p-1)=(34-3-1)=30, F_{(0,1 ; 3-2,34-3-1)}=F_{(0,1 ; 1,30)}=2,88$ 
Karena $\quad F_{\text {hitung }}=10,5419>F_{(0,1 ; 1,30)}=2,88$ maka $H_{0}$ ditolak yang berarti Persentase Penduduk Miskin berpengaruh signifikan terhadap Indeks Keparahan Kemiskinan.

g. Model (10)

$H_{0}: \beta_{1}=0$ (Gini Rasio tidak berpengaruh signifikan terhadap Indeks Keparahan Kemiskinan)

$H_{1}: \beta_{1} \neq 0$ (Gini Rasio berpengaruh signifikan terhadap Indeks Keparahan Kemiskinan)

Dengan statistik uji: $F_{m}=\frac{S T R_{\text {reduced }}-S T R_{\text {full }}}{(p-q) \hat{\lambda}}=\frac{0,199080-0,233167}{(3-2) 0,0085244}=-3,99874$

$p=3, q=2,(n-p-1)=(34-3-1)=30, F_{(0,1 ; 3-2,34-3-1)}=F_{(0,1 ; 1,30)}=2,88$

Karena $F_{\text {hitung }}=-3,99874<F_{(0,1 ; 1,30)}=2,88$ maka gagal menolak $H_{0}$ yang berarti Gini Rasio tidak berpengaruh signifikan terhadap Indeks Keparahan Kemiskinan.

Dari uji signifikan reduced dapat disimpukan bahwa faktor yang berpengaruh terhadap Indeks Keparahan Kemiskinan $(Y)$ adalah Persentase Penduduk Miskin $\left(X_{2}\right)$.

\section{Kesimpulan}

Dari hasil pembahasan ini disimpulkan bahwa untuk memperoleh estimasi koefisien regresi robust menggunakan estimasi- $M$, diperlukan sebelas iterasi dengan persamaan

$\hat{Y}=1,36552+0,45657 X_{1}+0,05772 X_{2}-0,01712 X_{3}$

yang menunjukkan bahwa untuk peningkatan setiap satu satuan Gini Ratio $\left(X_{1}\right)$ dan Persentase Penduduk Miskin $\left(X_{2}\right)$, maka Indeks Keparahan Kemiskinan juga meningkat masing-masing sebesar 0.45657 dan 0.05772. Peningkatan satu satuan Angka Partisipasi Murni $\left(X_{3}\right)$ akan menurunkan Indeks Keparahan Kemiskinan $(Y)$ sebesar 0,01712.

Model ini memiliki nilai $R$-square $=94,80 \%$ yang berarti variabel independen yang digunakan dalam model (Gini Ratio $\left(X_{1}\right)$ dan Persentase Penduduk Miskin $\left(X_{2}\right)$, dan Angka Partisipasi Murni $\left(X_{3}\right)$ ) mampu menjelaskan sebesar 94,80\% variasi variabel dependen (Indeks Keparahan Kemiskinan $(Y)$ ), sedangkan sisanya sebesar 5,2\% dipengaruhi atau dijelaskan oleh variabel lain yang tidak dimasukkan dalam model tersebut. Faktor yang berpengaruh terhadap Indeks Keparahan Kemiskinan $(Y)$ menurut hasil uji signifikansi reduced adalah Persentase Penduduk Miskin $\left(X_{2}\right)$. 


\section{Daftar Pustaka}

[1] Claro, S., Paunesku, D., and Dweck, C. S. Growth Mindset tempers the Effect of Poverty on Academic Achievement. Proceedings of the National Academy of Science of the United States of America. 8(9). 2016.

[2] Fan, S., Hazell, P., and Thorat, S. Government spending, growth and poverty in rural India. American Journal of Agricultural Economics. 82(4): 1038-1051. 2000.

[3] Yacoub, Y. Pengaruh Tingkat Pengangguran Terhadap Tingkat Kemiskinan Kabupaten/Kota di Provinsi Kalimantan Barat. Journal Eksos. 8(3). 2010.

[4] Badan Pusat Statistika. Indikator Kesejahteraan Rakyat 2019. Jakarta. Badan Pusat Statistik. 2019.

[5] Ferezagia, D. V. Analisis Tingkat Kemiskinan di Indonesie. Jurnal Sosial Humaniora Terapan. 1(1). 2018.

[6] Jonaidi, A. Analisis Pertumbuhan Ekonomi dan Kemiskinan di Indonesia. Jurnal Kajian Ekonomi. Volume 1 No 1. 2012.

[7] Tanti, W. A. Perbandingan Metode Kuadrat Terkecil dengan Metode Regresi Komponen Utama pada Kasus Multikolinearitas. Skripsi. Padang: Univesitas Andalas Padang. 2013.

[8] Fox, J. and Weisberg, S. Robust Regression in $R$ "An Appendix to An $R$ Companion to Applied Regression, Second Edition”. New York. 2012.

[9] Kurniawati, L. D. Kekekaran Regresi Linear Ganda dengan Estimasi MM (Method of Moment) dalam Mengatasi Pencilan. Skripsi. Yogyakarta. Universitas Negeri Yogyakarta. 2011.

[10] Montgomery, D. C. and Peck, E. A. Introduction to Linear Regression Analysis. John Wiley \& Sons Inc. New York. 2006.

[11] Li, S. Z., Wang, H., and Soh, W. Y. C. Robust Estimation of Rotation Angle from Image Sequences Using the Annelling M Estimator. Journal of Mathematical Imaging and Vision. 8(2): 181-192. 1998.

[12] Susanti, Y., Handayani, S. S., and Pratiwi, H. M Estimation, S Estimation, and MM Estimation in Robust Regression, International Journal of Pure and Applied Mathematics. 91(3): 349-360. 2014.

[13] Birkes, D. and Dodge, Y. Alternative Methods of Regression. John Wiley \& Sons Inc. New York. 1993. 